\title{
Spatial Distribution of Runoff Depth from a Watershed Located in a Cuesta Relief Area of São Paulo State, Brazil
}

\author{
Luiz Alberto Blanco Jorge ${ }^{1}$, Maria Helena Moraes ${ }^{2}$, Sérgio Lázaro de Lima ${ }^{2}$ \\ ${ }^{1}$ Department of Forest Science, School of Agronomic Sciences-FCA/UNESP, Botucatu, Brazil \\ ${ }^{2}$ Department of Soils and Environmental Resources, School of Agronomic Sciences-FCA/UNESP, Botucatu, Brazil \\ Email: blanco@fca.unesp.br, mhmoraes@fca.unesp.br, sergiolima@fca.unesp.br
}

Received December 19, 2013; revised January 18, 2014; accepted February 15, 2014

Copyright (c) 2014 Luiz Alberto Blanco Jorge et al. This is an open access article distributed under the Creative Commons Attribution License, which permits unrestricted use, distribution, and reproduction in any medium, provided the original work is properly cited. In accordance of the Creative Commons Attribution License all Copyrights (C) 2014 are reserved for SCIRP and the owner of the intellectual property Luiz Alberto Blanco Jorge et al. All Copyright (C) 2014 are guarded by law and by SCIRP as a guardian.

\begin{abstract}
This study was undertaken in a 1566 ha drainage basin situated in an area with cuesta relief in the state of São Paulo, Brazil. The objectives were: 1) to map the maximum potential soil water retention capacity, and 2) to simulate the depth of surface runoff in each geographical position of the area based on a typical rainfall event. The database required for the development of this research was generated in the environment of the geographical information system ArcInfo v.10.1. Undeformed soil samples were collected at 69 points. The ordinary kriging method was used in the interpolation of the values of soil density and maximum potential soil water retention capacity. The spherical model allowed for better adjustment of the semivariograms corresponding to the two soil attributes for the depth of 0 to $20 \mathrm{~cm}$, while the Gaussian model enabled a better fit of the spatial behavior of the two variables for the depth of 20 to $40 \mathrm{~cm}$. The simulation of the spatial distribution revealed a gradual increase in the depth of surface runoff for the rainfall event taken as example $(25 \mathrm{~mm})$ from the reverse to the peripheral depression of the cuesta (from west to east). There is a positive aspect observed in the gradient, since the sites of highest declivity, especially those at the front of the cuesta, are closer to the western boundary of the watershed where the lowest depths of runoff occur. This behavior, in conjunction with certain values of erodibility and depending on the land use and cover, can help mitigate the soil erosion processes in these areas.
\end{abstract}

\section{KEYWORDS}

\section{Geostatistical Analysis; Soil Density; Water Retention; Geographic Information System}

\section{Introduction}

Among the descriptive and interpretative aspects of an environmental diagnosis, it is important to include an understanding of how the land and natural resources are used, considering degradations, threats, and an estimate of the fragility or vulnerability for the development of human activities [1].

Water erosion assessment, which is part of the diagnosis of environmental problems, is highly relevant since inadequate land use can accelerate naturally occurring erosion and deposition processes, leading to modifications in soil conservation, water production and quality, and environmental changes in certain locations of a drainage basin [2]. Various approaches and equations for risk assessment or predictive evaluation of soil erosion by water are available in the literature. These approaches include the Universal Soil Loss Equation-USLE [3,4] and its derivatives Revised Universal Soil Loss Equation-RUSLE [5,6] and Modified Universal Soil Loss Equation-MUSLE [7].

The environment associated with cuesta relief areas in the state of São Paulo, Brazil, is extremely fragile and subject to different forms of negative impacts, including soil erosion [2]. Under these conditions, in studies developed in drainage basins, it is important to estimate sediment yield from a rainfall event or set of events. This estimation can be performed using the MUSLE model.

The curve number method of the USDA Natural Resources Conservation Service is often used to calculate surface runoff [8-13], which is one of the variables of the MUSLE. By designing the MUSLE as a distributed 
model, and considering investigations of small watersheds located in cuesta regions in Brazil, surface runoff can be quantified based on an approach that is closer to local reality, rather than on tabulated values related to the curve number method. The maximum potential soil water retention capacity is then mapped based on undeformed soil samples and geostatistical analyses. In this regard, the objectives of this study were: 1 ) to map the maximum potential soil water retention capacity of the soil in a drainage basin, and 2) to simulate the depth of runoff at each geographical position in the study area, based on a typical rainfall event. The database required for the development of this research was generated in the GIS environment of ArcInfo v.10.1.

\section{Material and Methods}

\subsection{Study Area}

The 1566 ha drainage basin (Figure 1) is located between the latitudes $22^{\circ} 47^{\prime} 49^{\prime \prime S}$ and $22^{\circ} 50^{\prime} 51^{\prime \prime S}$ and longitudes $48^{\circ} 22^{\prime} 51^{\prime \prime} \mathrm{W}$ and $48^{\circ} 25^{\prime} 35^{\prime \prime} \mathrm{W}$, in the municipality of Botucatu, state of São Paulo, Brazil. It comprises: 1) a small area at the reverse of the cuesta (beginning of the Eastern São Paulo Plateau), with altitudes of 710 to 810 $\mathrm{m}$; 2) the front of the cuesta (a sandstone and basaltic escarpment with its derived soils); and 3) a peripheral depression segment with altitudes of 465 to $600 \mathrm{~m}$, comprising an area of sandstone and alluvial sediments en- compassing the Capivara River wetlands. The soils of the basin's flat wetlands are Dystric Fluvisols, Mollic Gleysols and Dystric Gleysols. Toward the front of the cuesta but still within the peripheral depression are numerous gently undulating acclivities (2\% to 20\% slopes) with Albic Arenosols, Acrylic Ferralsols, Rhodic Ferralsols, Chromic Luvisols, Dystric Nitosols and Haplic Chernozems. The front of the basaltic cuesta contains Lithosols on $20 \%$ to $40 \%$ slopes [2].

The climate has two distinct seasons, one hot and rainy (September to March) and the other dry and cold (April to August). The native vegetation, which loses its leaves partially in the dry cold season, is classified as Seasonal Semideciduous Forest, with fragments of altered forest that have undergone various levels of anthropic disturbance. Fragments of natural vegetation, a transition of forest to forested savanna and gallery forest are also present. The land is used mainly as pasture. Small areas comprise planted forests and cultivated farmland [2].

\subsection{Collection of Undeformed Soil Samples}

Undeformed soil samples were collected at 69 points in the drainage basin (Figure 2). The soil sampling points were chosen from a regular $500 \times 500 \mathrm{~m}$ grid allocated in the area. The volume of the rings used in the soil extraction corresponded to $100 \mathrm{~cm}^{3}$. The samples were collected at two depths: $0-20 \mathrm{~cm}$ and $20-40 \mathrm{~cm}$.

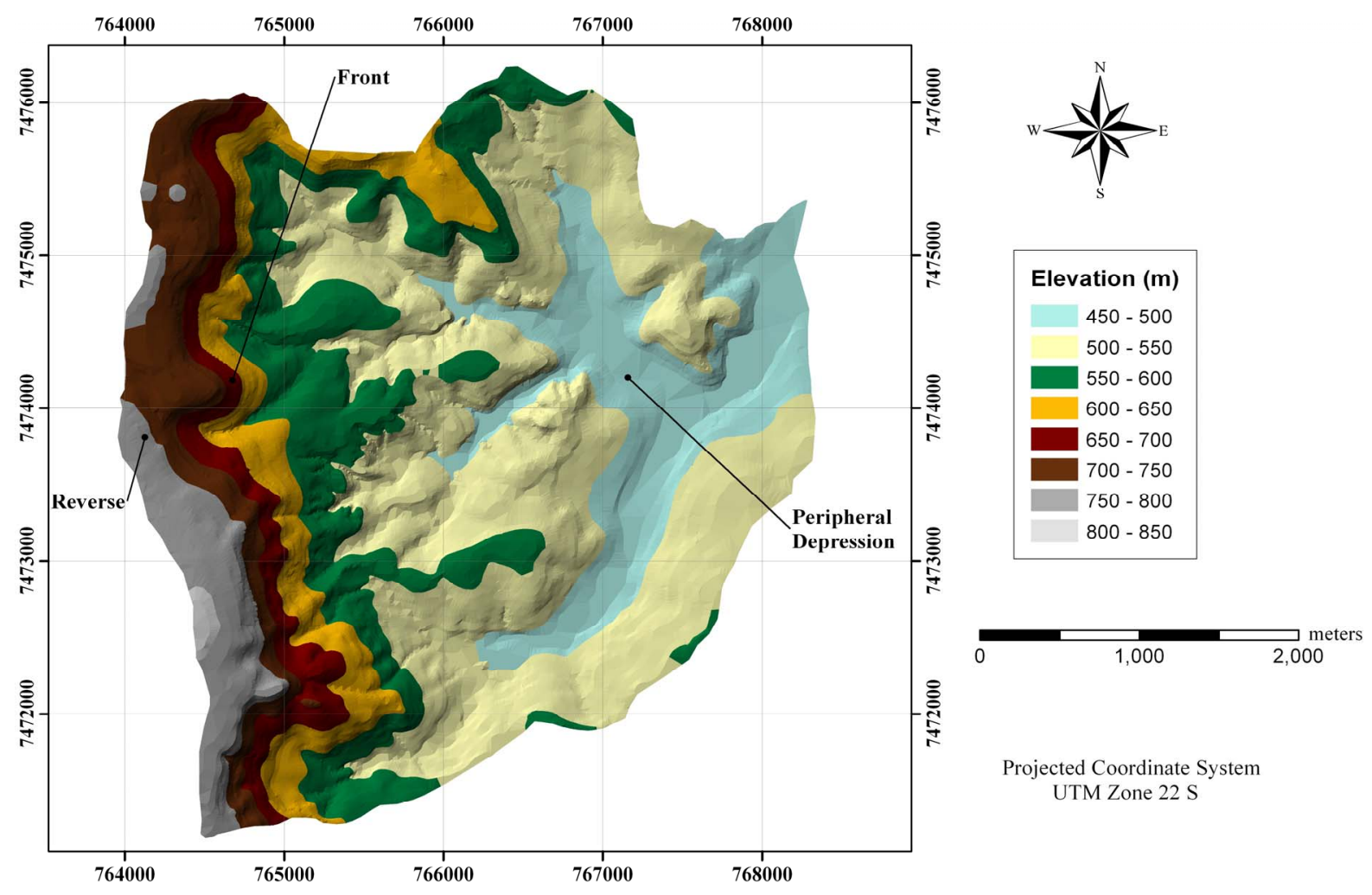

Figure 1. Digital elevation model of the drainage basin under study. 


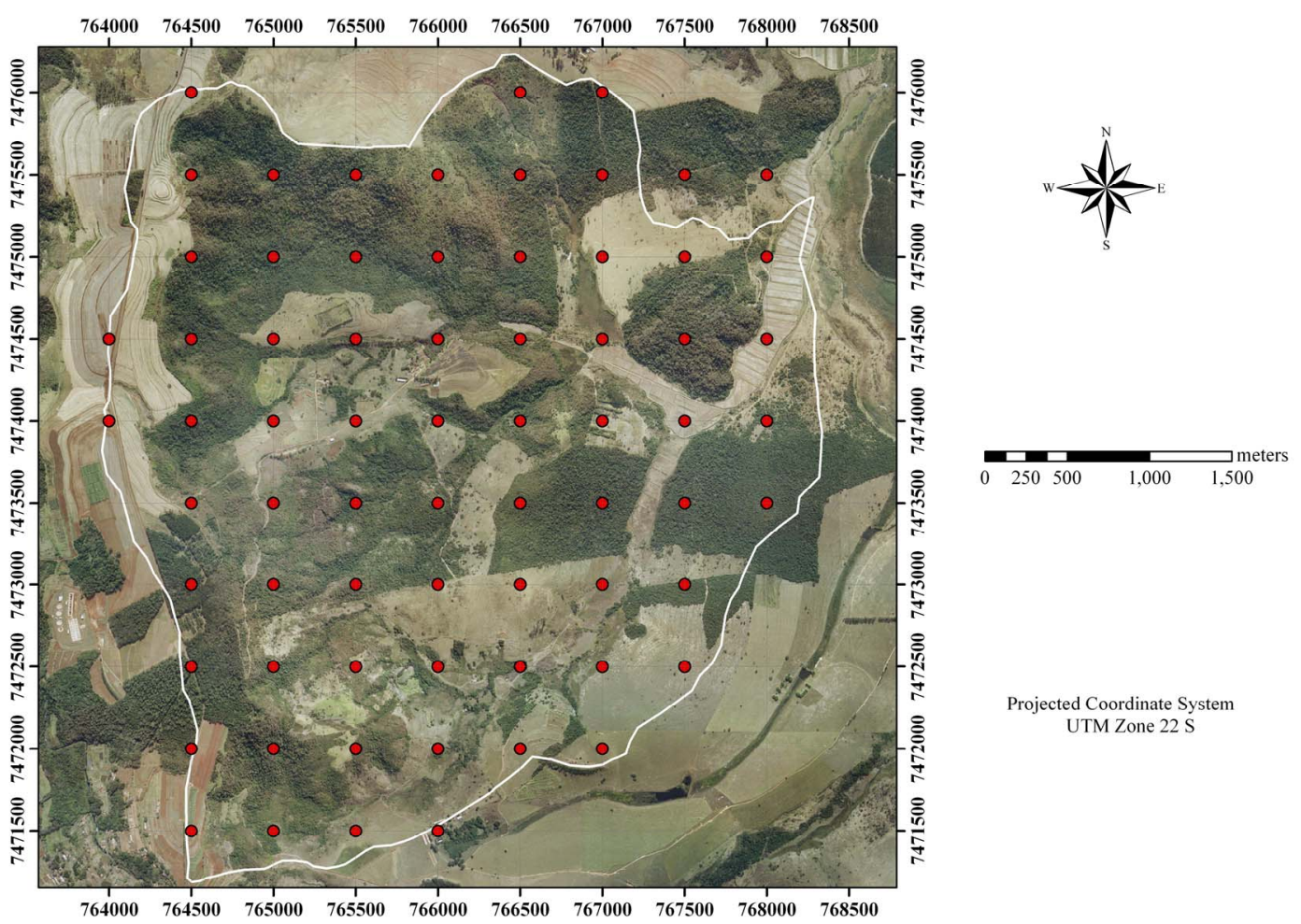

Figure 2. Collection points of undeformed soil samples located on an aerial photograph.

In the Soil Physics laboratory, the lower part of each ring of the undeformed soil samples was wrapped in a porous membrane. The samples were placed on trays containing distilled water up to half the height of the cylindrical ring. After the soil became saturated, the samples were weighed, placed in an oven at a temperature of $105^{\circ} \mathrm{C}$ for 48 hours, and then weighed again. The soil density $\left(\mathrm{kg} / \mathrm{dm}^{3}\right)$ and maximum potential soil water retention capacity (mm) were then determined.

\subsection{Geostatistical Analysis}

The ordinary kriging method was used to interpolate the values of soil density and maximum potential soil water retention capacity, which had been determined for the sampling points. In the geostatistical analysis, the linear, exponential, spherical and Gaussian models were tested in the GS + v.9.0 software environment. The following parameters were obtained from the best fit of the semivariogram for each assessed variable: the nugget effect $\left(\mathrm{C}_{0}\right)$, the sill $\left(\mathrm{C}_{0}+\mathrm{C}\right)$, and the range of spatial dependence $\left(A_{0}\right)$. The degree of spatial dependence (DSD) of the variables was calculated considering the nugget and sill effects.

A minor adaptation of a previously established classification of spatial dependence had to be made [14], considering that: the spatial dependence was weak when the DSD was less than or equal to $25 \%$, the spatial dependence was moderate when the DSD was higher than $25 \%$ but less than or equal to $75 \%$, and the spatial dependence was strong when the DSD exceeded $75 \%$.

In cross-validation [15-17], each measured point is excluded and its value is estimated with the remaining data, i.e., the cross-validation estimates the values of the variable under study at the same sampled points and compares the new values with the measured data. In this stage, the selected models, the values of the adjusted parameters and the quality of kriging were assessed.

The thematic plans were generated in the environment of the ArcInfo v.10.1 geographic information system, with the variables of soil density and maximum potential soil water retention capacity represented continuously. Raster plans were obtained with the pixels showing a spatial resolution of 10 meters.

\subsection{Calculation of Surface Runoff in a Rainfall Event}

The layers of surface runoff depth and volume were produced from a typical rainfall event. In general, surface runoff is calculated based on the widely used curve number method of the USDA Natural Resources Conservation Service. The theory of the curve number method is based on the assumption that, for a rainfall event, the ratio of the depth of runoff to rainfall is equal to the ratio of the real retention (rain not converted into runoff) after the onset of runoff to the maximum potential retention [11], according to Equation (1): 


$$
\frac{Q_{d}}{R}=\frac{F}{S}
$$

where:

$Q_{d}=$ depth of runoff (mm);

$R=$ rainfall event (mm);

$F=$ real retention after the onset of runoff (mm);

$S=$ parameter of potential retention of the soil and the cover conditions.

When the initial abstraction ( $I a)$ is considered, the amount of rainfall available in surface runoff is $(R-I a)$. The real retention is the difference between rainfall and depth of surface runoff $\left(F=R-Q_{d}\right)$ [11]. The depth of surface runoff was calculated from the rainfall and the maximum potential retention, by means of Equations (2) and (3):

$$
\begin{gathered}
Q_{d}=\frac{(R-0.2 S)^{2}}{(R+0.8 S)} \quad(\text { if } R>0.2 S) \\
Q_{d}=0 \quad(\text { if } R \leq 0.2 S)
\end{gathered}
$$

In this study, the maximum potential soil water retention capacity was determined based on the map produced with the aid of the undeformed soil samples rather than on tabulated data published by the USDA Natural Resources Conservation Service. After quantifying and generating the raster plan for depth of runoff $\left(Q_{d}\right)$, the volume of surface runoff, in $\mathrm{m}^{3}(Q)$, was calculated for each cell, in which the depth (transformed from millimeters into meters) was multiplied by the area of the pixel (100 $\mathrm{m}^{2}$ ), and for the entire drainage basin.

\section{Results}

The two-parameter Weibull distribution (b and c, involving scale and shape, respectively) was used to describe the frequency distributions (Table 1 and Figure 3) of the variables subjected to geostatistical analysis (soil density and maximum potential soil water retention capacity at depths of $0-20$ and $20-40 \mathrm{~cm}$ ). The parameters were estimated by the percentile method. The adjustment was evaluated according to the adjustment in-

\begin{tabular}{|c|c|c|c|c|c|}
\hline \multirow{2}{*}{ Variable } & \multicolumn{2}{|c|}{ Estimators } & & & \multirow{2}{*}{$\begin{array}{l}\text { Coefficient of } \\
\text { variation }(\%)\end{array}$} \\
\hline & $\mathbf{b}$ & c & $\begin{array}{c}\mathrm{AI} \\
(\%)\end{array}$ & Mean & \\
\hline $\begin{array}{c}\text { Soil density at } 0-20 \\
\mathrm{~cm}\left(\mathrm{~kg} / \mathrm{dm}^{3}\right)\end{array}$ & 0.5883 & 3.7409 & 98.27 & 1.53 & 10.34 \\
\hline $\begin{array}{c}\text { Soil density } \\
\text { at } 20-40 \mathrm{~cm}\left(\mathrm{~kg} / \mathrm{dm}^{3}\right)\end{array}$ & 0.5652 & 4.6324 & 95.39 & 1.62 & 7.85 \\
\hline $\begin{array}{l}\text { Soil water retention } \\
\text { at } 0-20 \mathrm{~cm}(\mathrm{~mm})\end{array}$ & 10.0822 & 2.0938 & 99.49 & 22.93 & 19.54 \\
\hline $\begin{array}{l}\text { Soil water retention } \\
\text { at } 20-40 \mathrm{~cm}(\mathrm{~mm})\end{array}$ & 9.4514 & 1.7829 & 98.82 & 21.41 & 22.78 \\
\hline
\end{tabular}

Table 1. Estimators and statistics of the Weibull distribution of the variables subjected to geostatistical analysis. dex (AI). The values of the mean and variance of the variables were calculated using the formulas related to the Weibull function, which required the use of the Gamma function [18]. It is important to point out, for the two sampled soil depths: 1) the greater variability of the attribute maximum potential soil water retention capacity than that of the soil density (Table 1) and 2) the strongly negative correlation between the two soil attributes (Figure 4).

The spherical model allowed for a better fit of the semivariograms corresponding to the variables of soil density and maximum potential soil water retention capacity for the depth of $0-20 \mathrm{~cm}$ (Table 2, Figures 5(a) and (c)), while the Gaussian model was better suited to the spatial behavior of the two variables for the depth of $20-40 \mathrm{~cm}$ (Table 2, Figures 5(b) and (d)). The soil density and maximum potential soil water retention capacity at $0-20$ $\mathrm{cm}$ depth showed a moderate spatial dependence, while at the depth of $20-40 \mathrm{~cm}$ they presented a strong spatial dependence. Land use was found to influence the degree of spatial dependence (DSD) (Table 2) of the variables under study, reflecting the changes caused by human action, which are more pronounced at the surface.

The cross-validation allowed for an analysis of the relationship between the observed and estimated values after adjustment of the semivariograms (Table 3 and

Table 2. Semivariogram models adjusted to the variables of

\begin{tabular}{|c|c|c|c|c|c|}
\hline \multirow{2}{*}{ Variable } & \multirow{2}{*}{ Model } & \multicolumn{3}{|c|}{ Parameters } & \multirow{2}{*}{$\begin{array}{l}\text { DSD } \\
(\%)\end{array}$} \\
\hline & & $\mathrm{C}_{0}$ & $\mathrm{C}_{0}+\mathrm{C}$ & $\overline{A_{0}}$ & \\
\hline $\begin{array}{c}\text { Soil density at } 0-20 \mathrm{~cm} \\
\left(\mathrm{~kg} / \mathrm{dm}^{3}\right)\end{array}$ & Spherical & 0.01507 & 0.04364 & 3550 & 65.5 \\
\hline $\begin{array}{c}\text { Soil density at } \\
20-40 \mathrm{~cm}\left(\mathrm{~kg} / \mathrm{dm}^{3}\right)\end{array}$ & Gaussian & 0.01200 & 0.07000 & 2810 & 82.4 \\
\hline $\begin{array}{l}\text { Soil water retention } \\
\text { at } 0-20 \mathrm{~cm}(\mathrm{~mm})\end{array}$ & Spherical & 6.13 & 20.81 & 3340 & 70.5 \\
\hline $\begin{array}{l}\text { Soil water retention } \\
\text { at } 20-40 \mathrm{~cm}(\mathrm{~mm})\end{array}$ & Gaussian & 6.06 & 34.79 & 2960 & 82.6 \\
\hline
\end{tabular}
soil density and maximum potential soil water retention capacity.

$\mathrm{C}_{0}$ : nugget effect; $\mathrm{C}_{0}+\mathrm{C}$ : sill; $\mathrm{A}_{0}$ : range; DSD: degree of spatial dependence.

Table 3. Results of the cross-validation for the semiva- riogram models adjusted to the variables of soil density and maximum potential soil water retention capacity.

\begin{tabular}{cccc}
\hline \multirow{2}{*}{ Variable } & \multicolumn{2}{c}{ Coefficients } & \\
\cline { 2 - 4 } & Intersection Slope & SE(\%) \\
\hline Soil density at $0-20 \mathrm{~cm}\left(\mathrm{~kg} / \mathrm{dm}^{3}\right)$ & 0.190 & 0.8730 .165 & 10.78 \\
$\begin{array}{c}\text { Soil density at } 20-40 \mathrm{~cm}\left(\mathrm{~kg} / \mathrm{dm}^{3}\right) \\
\text { Soil water retention at } 0-20 \mathrm{~cm} \\
(\mathrm{~mm})\end{array}$ & 0.020 & 0.9880 .133 & 8.21 \\
$\begin{array}{c}\text { Soil water retention at } 20-40 \mathrm{~cm} \\
(\mathrm{~mm})\end{array}$ & 0.000 & 0.9962 .833 & 13.23 \\
\hline
\end{tabular}

SE: standard error of the estimate; SE(\%): standard error of the estimate, in percent. 


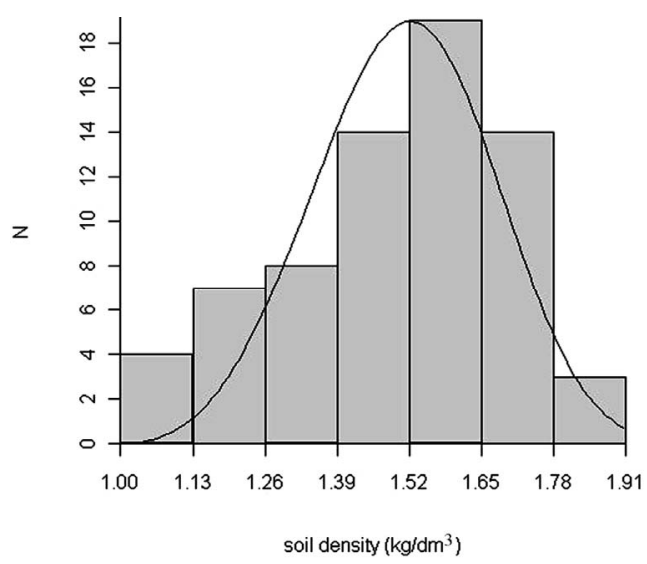

(a)

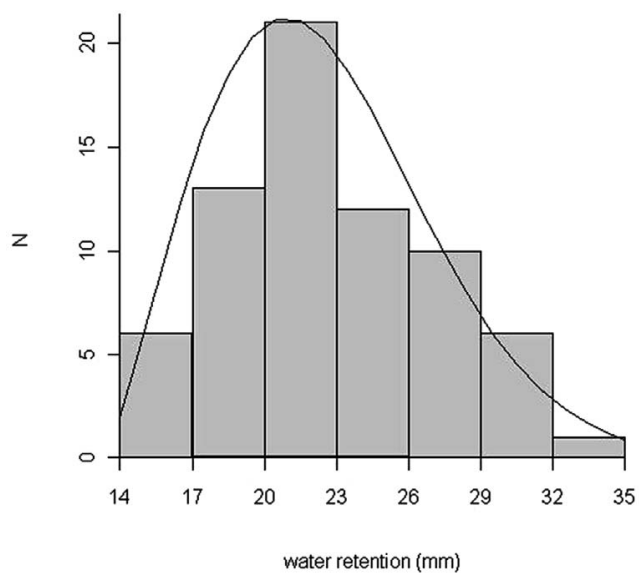

(c)

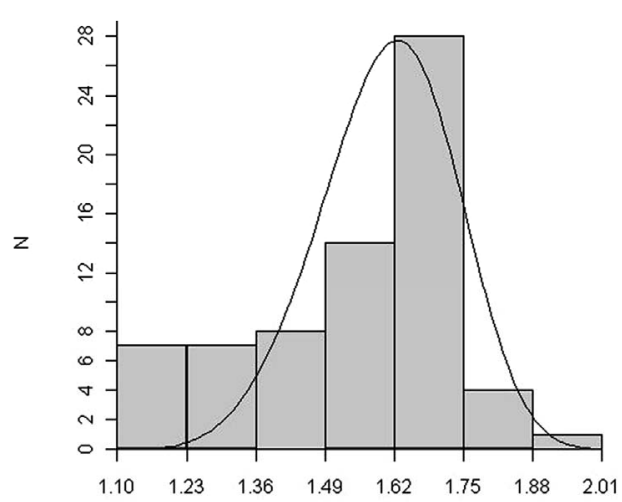

soil density $\left(\mathrm{kg} / \mathrm{dm}^{3}\right)$

(b)

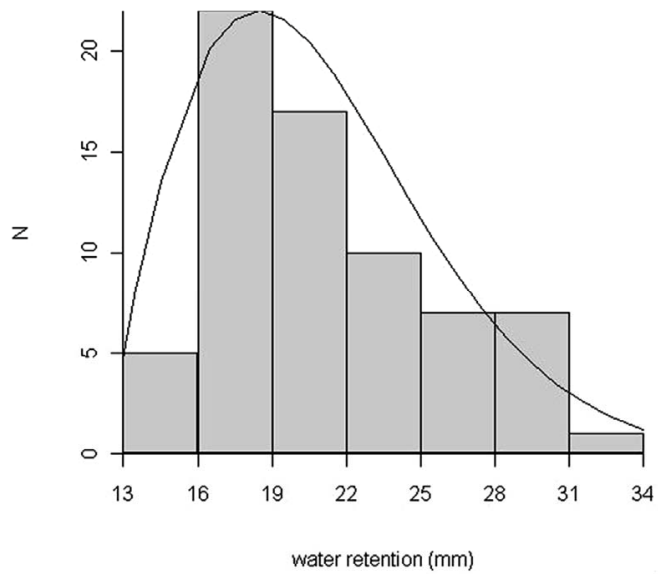

(d)

Figure 3. Frequency distribution of: a) Soil density at 0 - $20 \mathrm{~cm}$ depth; b) Soil density at $20-40 \mathrm{~cm}$ depth; c) Maximum potential soil water retention capacity at $0-20 \mathrm{~cm}$ depth; and d) Maximum potential soil water retention capacity at $20-40 \mathrm{~cm}$ depth.

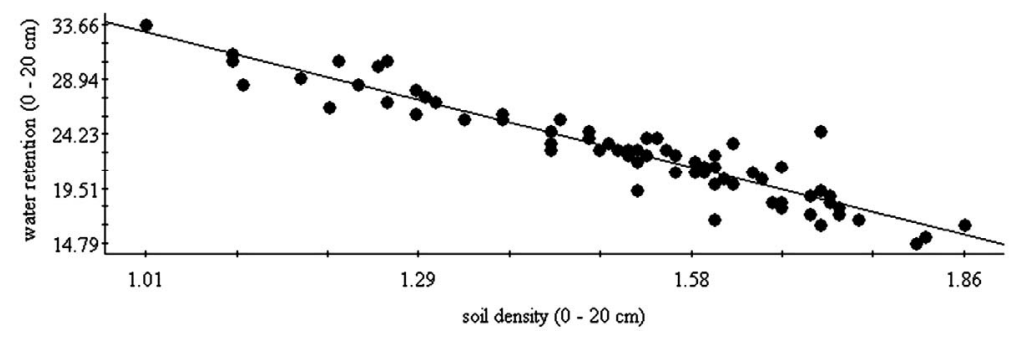

(a)

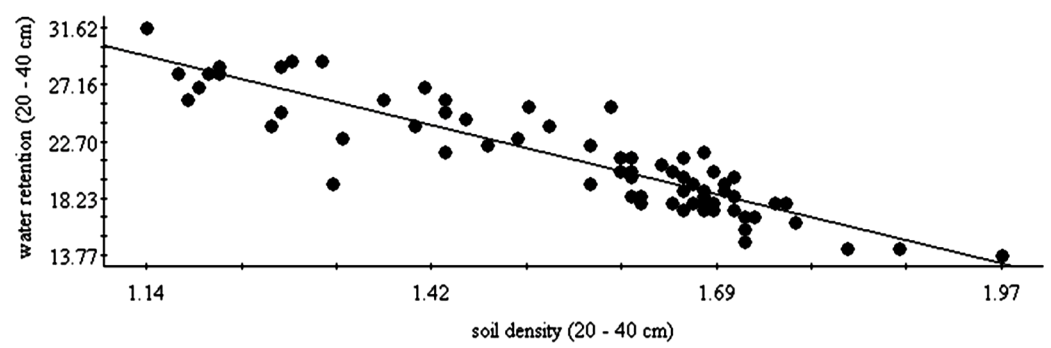

(b)

Figure 4. Relationship between soil density and maximum potential soil water retention capacity: a) At 0 - $20 \mathrm{~cm}$ depth (SE = $\left.0.92, \mathrm{SE} \%=4.01, \mathrm{R}^{2}=0.883, \mathrm{r}=-0.94\right)$; b) At $20-40 \mathrm{~cm}$ depth $\left(\mathrm{SE}=1.17, \mathrm{SE} \%=5.46, \mathrm{R}^{2}=0.806, \mathrm{r}=-0.90\right)$. 


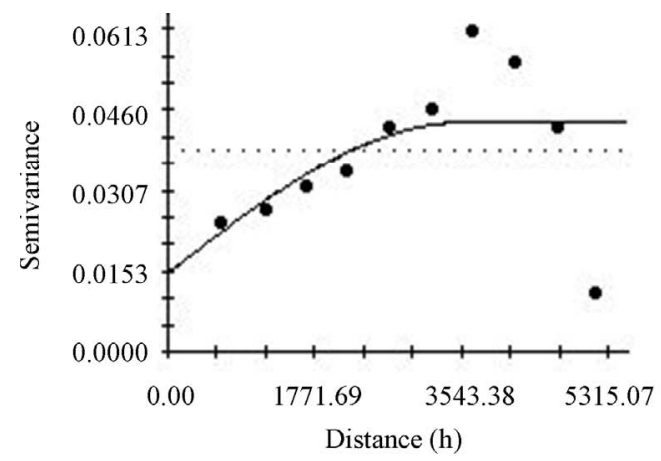

(a)

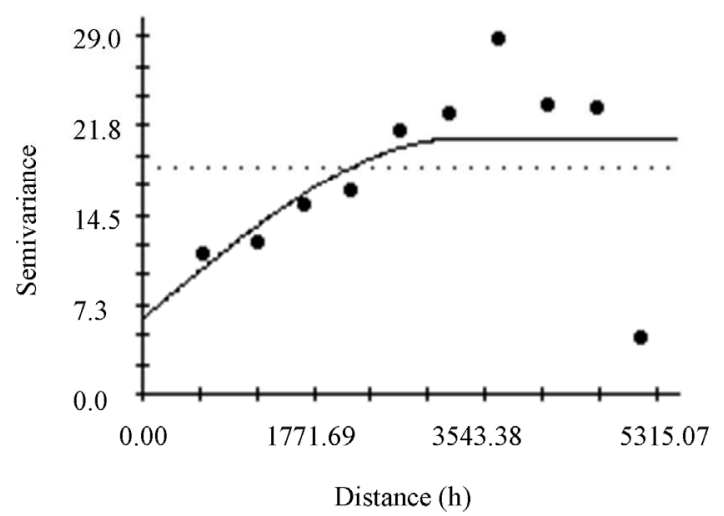

(c)

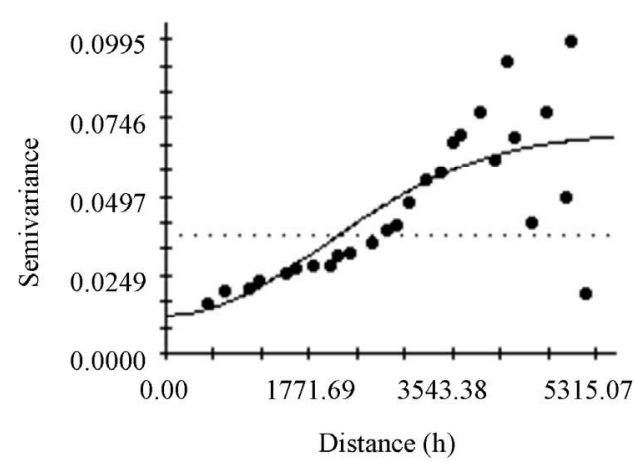

(b)

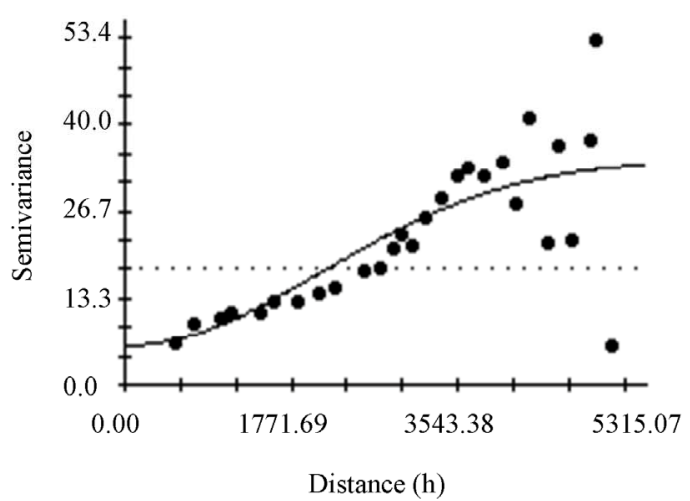

(d)

Figure 5. Adjusted semivariograms: a) Soil density at 0 - $20 \mathrm{~cm}$ depth; b) Soil density at 20 - $40 \mathrm{~cm}$ depth; c) Maximum potential soil water retention capacity at $0-20 \mathrm{~cm}$ depth; d) Maximum potential soil water retention capacity at $20-40 \mathrm{~cm}$ depth.

Figure 6). The regression coefficient or slope of the ideal straight line should be close to one, while the intersection coefficient should be located close to zero. This behavior was observed in the variables in question (Table 3 ), confirming the appropriateness of the adjustments. The standard error of estimate (SE) and standard error of estimate in percentage (SE \%) (Table 3) indicated the accuracy of the estimates, after adjustment of the semivariograms. The accuracy of the variable of soil density at both depths was appropriate. The accuracy of the variable of maximum potential soil water retention capacity can be considered acceptable in terms of: 1) the size of the area (1566 ha); 2) the natural variability of the soils and of this attribute in the drainage basin under study, which is located at the cuesta front; and 3) the increase in the attribute's variability at the surface due to anthropic activity.

The thematic plans corresponding to soil density (Figure 7) showed that the lowest values occurred to the west (reverse and front of the cuesta) and an increase from west to east (for the peripheral depression of the cuesta). Unlike the soil density, the plans corresponding to the potential maximum soil water retention capacity (Figure 8) presented the highest values in the western portion of the area (reverse and front of the cuesta) and a decrease from west to east (for the peripheral depression). The outlet of the drainage basin is to the east (Figure 1).

The historical rainfall data for two years (2011 and 2012) were analyzed, confirming that January is the wettest month of the year in the region, when the major storms occur. However, the spatial distribution of the depth of surface runoff (Figure 9) was simulated for a 25 $\mathrm{mm}$ rainfall event, which does not characterize a storm but an intermediate amount of rainfall, which relates to an event that may also occur in January. For this intensity of rainfall, the runoff volume calculated for the entire drainage basin was $152,574 \mathrm{~m}^{3}$.

\section{Conclusions and Recommendation}

The following conclusions were reached based on the results of this study:

1) The maximum potential soil water retention capacity showed a strong negative correlation with soil density, which strengthens the argument that, due to their structure, less dense soils are more porous and hence show a greater potential for water retention in macro- and micropores.

2) The relationship between the maximum potential water retention and soil density was reflected in the spatial distribution of these variables, revealing a greater poten- 


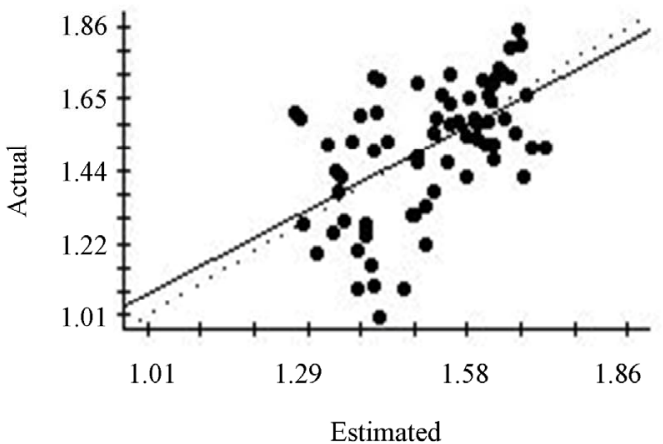

(a)

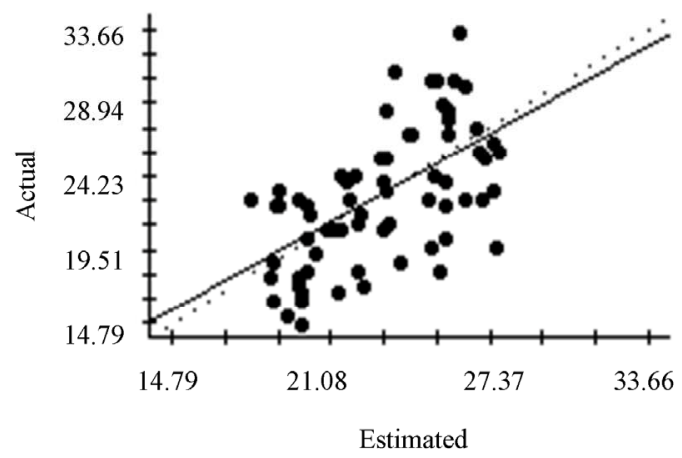

(c)

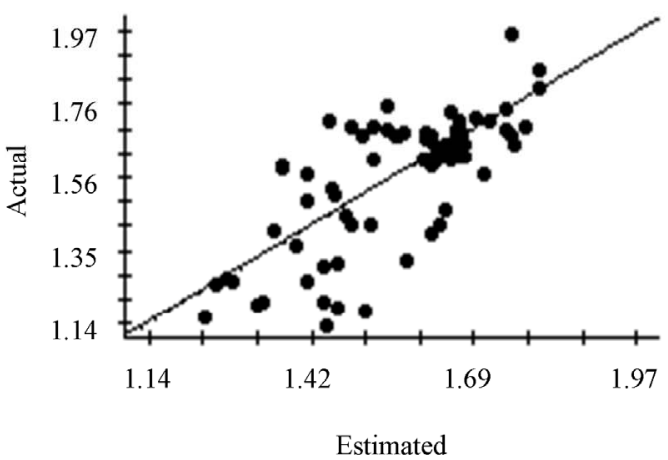

(b)

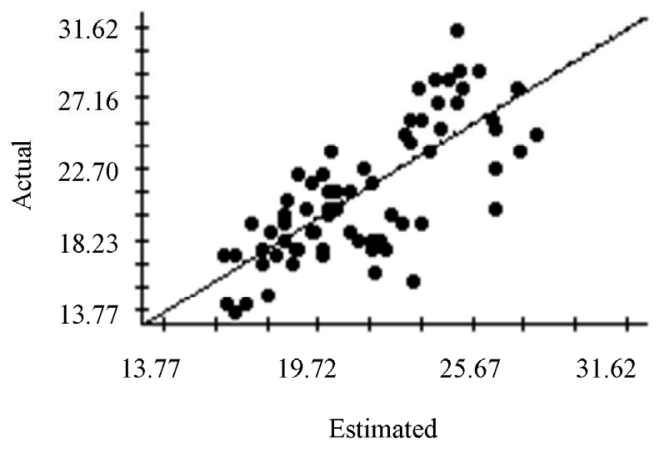

(d)

Figure 6. Relationship between the observed and estimated values after adjustment of the semivariograms: a) Soil density at 0 - $20 \mathrm{~cm}$ depth; b) Soil density at 20 - $40 \mathrm{~cm}$ depth; c) Maximum potential soil water retention capacity at 0 - $20 \mathrm{~cm}$ depth; d) Maximum potential soil water retention capacity at $20-40 \mathrm{~cm}$ depth.

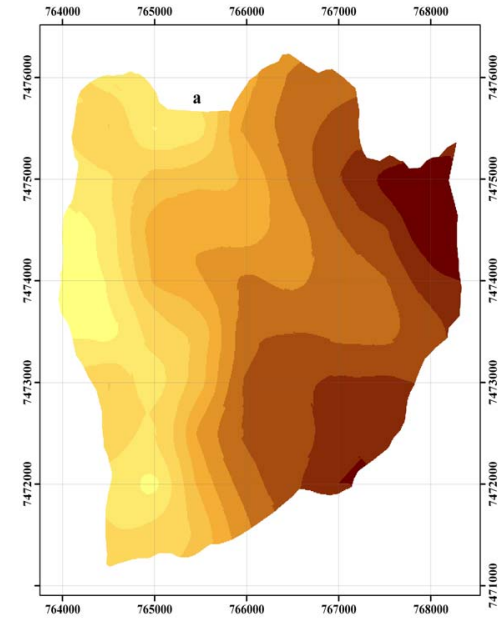

(a)

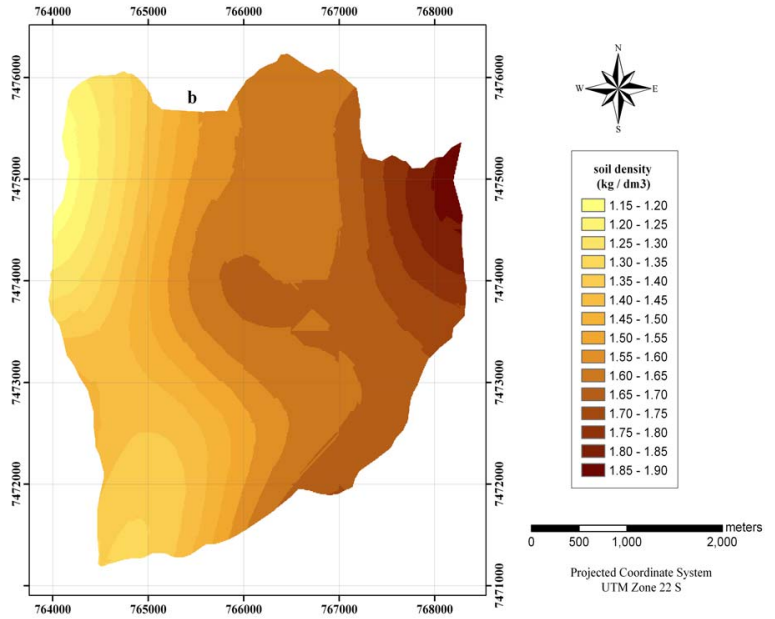

(b)

Figure 7. Spatial distribution of soil density in the drainage basin: a) at $0-20 \mathrm{~cm}$ depth; b) at $20-40 \mathrm{~cm}$ depth.

tial for water retention and a lower soil density in the reverse and front areas of cuesta, and a decrease in potential water retention and an increase in soil density, in a gradient, in the direction reverse to the peripheral depression, i.e., from west to east (where the outlet of the watershed is located).

The simulated spatial distribution revealed a gradual increase in the depth of surface runoff for the rainfall event taken as an example, from the reverse to the peripheral depression. The gradient observed here shows a 


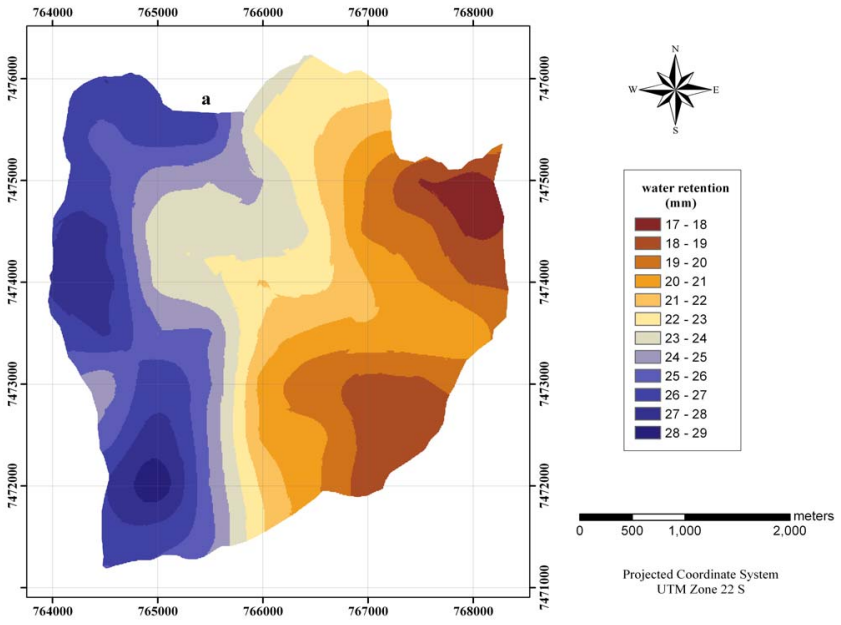

(a)

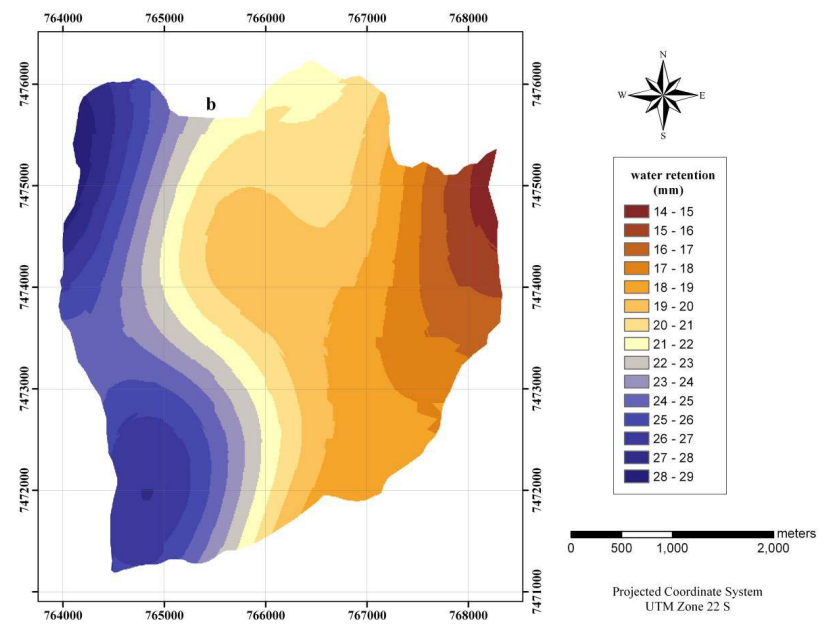

(b)

Figure 8. Spatial distribution of maximum soil water retention capacity in the drainage basin: a) At 0 - $20 \mathrm{~cm}$ depth; b) At 20 $-40 \mathrm{~cm}$ depth.

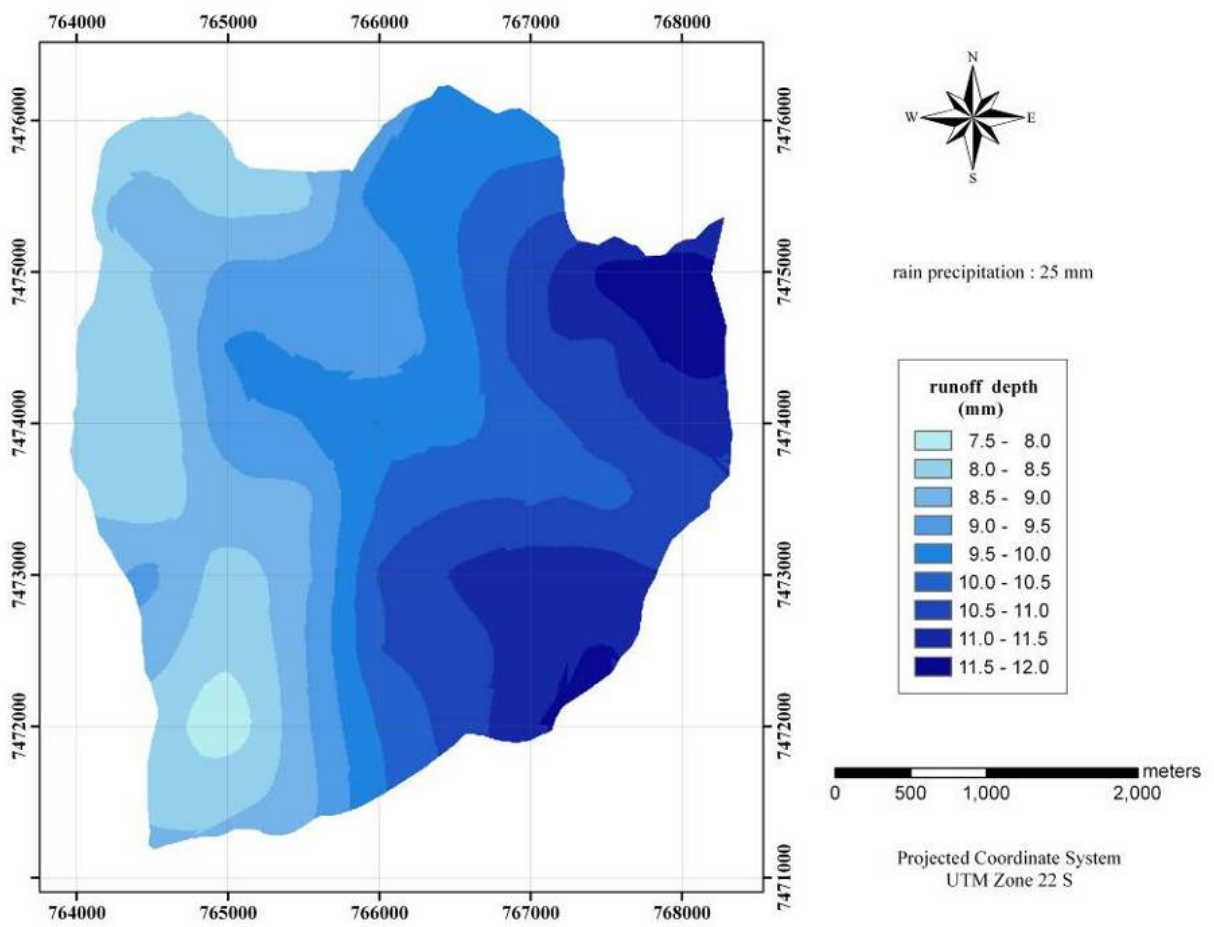

Figure 9. Spatial distribution of the depth of surface runoff in the watershed for a $25 \mathrm{~mm}$ rainfall event.

positive aspect, since the sites of greatest declivity, especially those at the front of the cuesta, are closer to the western boundary of the catchment basin, where the lowest depths of surface runoff occur. This behavior, in conjunction with certain values of erodibility and depending on land use and cover, can help mitigate the processes of soil erosion by water in these areas.

As a recommendation, based on the information garnered in this study in addition to other data already con- tained in the database of the area in question, it is suggested that a project be developed to raise funds for the installation of a hydrological station at or close to the outlet off this drainage basin. The data series on rainfall and runoff that would thus be obtained would allow for the development of several hydrology studies and also for the adjustment of the Modified Universal Soil Loss Equation-MUSLE to this site of reverse-front-peripheral depression contact in the cuesta. 


\section{REFERENCES}

[1] D. Gómez-Orea, “Ordenación Territorial,” Mundi-Prensa, Madrid, 2002.

[2] L. A. B. Jorge, "Soil Erosion Fragility Assessment Using an Impact Model and Geographic Information System," Scientia Agricola, Vol. 66, No. 5, 2009, pp. 658-666. http://dx.doi.org/10.1590/S0103-90162009000500011

[3] W. H. Wischmeier and D. D. Smith, "Predicting Rainfall Erosion Losses from Cropland East of the Rocky Mountains,” USDA/ARS, Washington, 1965.

[4] W. H. Wischmeier and D. D. Smith, "Predicting Rainfall Erosion Losses: A Guide to Conservation Planning with the Universal Soil Loss Equation (USLE)," USDA, Washington, 1978.

[5] K. G. Renard, G. R. Foster, D. C. Yoder and D. K. McCool, "RUSLE Revisited: Status, Question, Answers, and the Future," Journal of Soil and Water Conservation, Vol. 49, 1994, pp. 213-220.

[6] D. Yoder and J. Lown, "The Future of RUSLE: Inside the New Revised Universal Soil Loss Equation,” Journal of Soil and Water Conservation, Vol. 50, 1995, pp. 484-489.

[7] J. R. Williams, "Sediment Routing for Agricultural Watersheds,” Water Resource Bulletin, Vol. 11, No. 5, 1975, pp. 965-974. http://dx.doi.org/10.1111/j.1752-1688.1975.tb01817.x

[8] A. M. Melesse and S. F. Shih, "Spatially Distributed Storm Runoff Depth Estimation Using Landsat Images and GIS," Computers and Electronics in Agriculture, Vol. 37, No. 1-3, 2002, pp. 173-183. http://dx.doi.org/10.1016/S0168-1699(02)00111-4

[9] X. Zhan and M. Huang, "ArcCN-Runoff: An ArcGIS Tool for Generating Curve Number and Runoff Maps,” Environment Modelling and Software, Vol. 19, No. 10, 2004, pp. 875-879. http://dx.doi.org/10.1016/j.envsoft.2004.03.001

[10] R. Vijay, A. Pareek and A. Gupta, "Estimation of Rainfall-Runoff Using Curve Number: A GIS Based Development of Sathanur Reservoir Catchment," Journal of Environmental Science and Engineering, Vol. 48, No. 4, 2006, pp. 267-270.
[11] Y. Zhang, J. Degroote, C. Wolter and R. Sugumaran, "Integration of Modified Universal Soil Loss Equation (MUSLE) into a GIS Framework to Assess Soil Erosion Risk," Land Degradation \& Development, Vol. 20, No. 1, 2009, pp. 84-91. http://dx.doi.org/10.1002/ldr.893

[12] M. Ebrahimian, A. A. Nuruddin, M. A. B. M. Soom and A. M. Sood, "Application of NRCS-Curve number method for runoff estimation in a mountainous watershed," Caspian Journal of Environmental Sciences, Vol. 10, No. 1, 2012, pp. 103-114.

[13] G. B. Schultz, C. A. C. Siefert and I. Santos, “Avaliação do ArcMUSLE para Estimativa da Produção de Sedimentos na Bacia Hidrográfica do Alto Rio Negro, Região Sul Brasileira,” Boletim de Geografia, Vol. 31, No. 2, 2013, pp. 131-141. http://dx.doi.org/10.4025/bolgeogr.v31i2.13367

[14] C. A. Cambardella, T. B. Moorman, J. M. Novak, T. B. Parkin, D. L. Karlen, R. F. Turco and A. E. Konopka, "Field-Scale Variability of Soil Properties in Central Iowa Soils," Soil Science Society of America Journal, Vol. 58, No. 2, 1994, pp. 1501-1511. http://dx.doi.org/10.2136/sssaj1994.03615995005800050 $\underline{033 x}$

[15] E. H. Isaaks and R. M. Srivastava, "An Introduction to Applied Geoestatistics,” Oxford University Press, New York, 1989.

[16] R. M. Castro Junior, F. G. Sobreira and F. D. Bortoloti, "Modelagem Geoestatística a Partir de Parâmetros de Qualidade da Água (IQA-NSF) para a Sub-Bacia Hidrográfica do rio Castelo (ES) Usando Sistema de Informações Geográficas,” Revista Brasileira de Cartografia, Vol. 59, No. 3, 2007, pp. 241-253.

[17] N. M. Gomes, M. A. Faria, A. M. Silva, C. R. Mello and M. R. Viola, "Variabilidade Espacial de Atributos Físicos do solo Associados ao uso e Ocupação da Paisagem," Revista Brasileira de Engenharia Agrícola e Ambiental, Vol. 11, No. 4, 2007, pp.427-435. http://dx.doi.org/10.1590/S1415-43662007000400013

[18] E. T. Lee, "Statistical Methods for Survival Data Analysis,” Lifetime Learning Publications, Belmont, 1980. 